\title{
Green Campus Design for National Institute of Science and Technology: Implementing UI GreenMetric Criteria to Create Environmentally Friendly and Sustainable Campus
}

\author{
Jaka Fajar Fatriansyah ${ }^{1 *}$, Fahmi Alam Abdillah², Fathur Rahman Alfarizi ${ }^{3}$ \\ ${ }^{1}$ Department of Metallurgical and Materials Engineering, Faculty of Engineering, Universitas Indonesia, \\ Kampus UI Depok, Depok 16424, Indonesia \\ ${ }^{2}$ Civil Engineering Department, Faculty of Engineering, Universitas Jenderal Achmad Yani, Jawa Barat \\ 40532, Indonesia \\ ${ }^{3}$ Faculty of Medicine, Universitas Malahayati, Bandar Lampung 35152, Indonesia
}

\begin{abstract}
The National Institute of Science and Technology (ISTN) campus is a strategic location with a large green open space area. However, the ISTN campus has not been included in the ranking of the green campus category based on the UI GreenMetric. The UI GreenMetric is a set of guidelines for ranking environmentally friendly campuses based on six categories: Setting and Infrastructure (SI), Energy and Climate change (EC), Waste (WS), Water (WR), Transportation (TR), and Education and Research (ED). The purpose of this research is to transform the existing ISTN campus to make it fit the green campus criteria. The green campus master plan is created to increasing the score UI GreenMetric of the ISTN campus. The project is accomplished by conducting a site survey to determine the campus area and then analyzing the area parameters using ArcGIS, an application for making maps, analyzing data, and reporting the results. The design method applied after calculating the ISTN campus score is intended to increase the UI GreenMetric score of the campus and make it more environmentally friendly and sustainable. The design is prepared in Sketchup, an application used to produce 3D models. The result of this research is the total score of the UI GreenMetric analysis of the existing ISTN campus and the new ISTN green campus master plan design. This research is conducted with the hope that it will help the ISTN campus become an environmentally friendly and sustainable campus and qualify to enter the UI GreenMetric ranking.
\end{abstract}

Keywords: ArcGIS; Green campus; Master plan; Sketchup; UI GreenMetric

\section{Introduction}

The National Institute of Science and Technology (ISTN) campus is an institute located in the Jagakarsa area, South Jakarta City. The ISTN campus has a large area of green open space, but it has not yet entered the UI GreenMetric World University Ranking. It is possible to enter the ranking by transforming the available green open space into a green campus area (Atici et al., 2020).

UI GreenMetric is a guide for ranking environmentally friendly campuses based on six categories: Setting and Infrastructure (SI), Energy and Climate change (EC), Waste (WS), Water (WR), Transportation (TR), and Education and Research (ED) (Suwartha and Berawi, 2019). According to the overall ranking for 2020, UI GreenMetric included 912 universities

${ }^{*}$ Corresponding author's email: jakafajar@ui.ac.id, Tel.: +62-22-2508124

doi: 10.14716/ijtech.v12i5.5283 
in 84 countries. The ranking criteria facilitate the design of new high-standard plans and concepts for universities and institutes (Binta and Maulana, 2021).

The aim of this study is to transform the ISTN campus into a green campus and enter the UI GreenMetric ranking, which requires analysis of the UI GreenMetric score and design of a green campus master plan to increase the UI GreenMetric score of the campus. To improve education well-being by considering environmental sustainability is the Sustainable Development Goals (SDGs) (Berawi, 2021). The universities and institutes are enabling to lead the way in SDGs (Parvez and Agrawal, 2019).

A green campus concept is adopted by many universities and institutes. Managing such campuses systematically, the university or the institute is expected to create a place that refers to green campus concept (Santoso et al., 2017; Dagiliūtè et al., 2018; Binta and Maulana, 2021). In this study, UI GreenMetric criteria will be used as a set of basic parameters to design a sustainable and environmentally friendly campus. The high education contributions to achieve sustainable development can be obtained via education, buildings, and research (Abdallah, 2018). The importance of sustainable development is to protect the environment (Russ et al., 2018; Le, 2018).

The UI GreenMetric score analysis of this study is based on the 2021 UI GreenMetric guidelines, assisted by ArcGIS, an application for making maps, analyzing data, and reporting the results, used to calculate the required area and Sketchup, an application to produce 3D models, used to design a green campus master plan.

This research of the green open space of the ISTN campus area includes analysis of various aspects, such as waste management, energy and water use, transportation, and education facilities, according to the criteria of the UI GreenMetric.

\section{Methods}

\subsection{Description of Study Area}

ISTN is located between $6^{\circ} 21^{\prime} 13^{\prime \prime} \mathrm{S}$ and $106^{\circ} 48^{\prime} 46^{\prime \prime} \mathrm{E}$ in the Jagakarsa District, Jakarta City. Its campus's facilities include a rectorate building, hall, library, lecture hall, room lecturers, laboratories, polyclinic canteens, lakes, etc. The area of the green open space of ISTN is $8 \mathrm{Ha}$ and the total area of the institute is $11.62 \mathrm{Ha}$, which means the green open area constitutes $30 \%$, making it possible to realize the green campus concept.

\subsection{Location Survey}

Location surveys are carried out by direct surveys at the research site assisted by drones to obtain research data, such as the number of buildings and the boundaries of the research area.

\subsection{Satellite Map}

The satellite map was obtained for this paper using the ArcGIS application. The procedure was as follows: first, an imagery is chosen at arcgis.com and opened as a highresolution satellite map in the desktop version of the application; then, the ISTN campus area is zoomed in to the scale of 1:280. The obtained satellite map serves as the basis for calculating the researched area. The ArcGIS application allows to calculate the campus area, the green open space area including the forest vegetation area and the area of the garden or plant vegetation, and the parking area. 

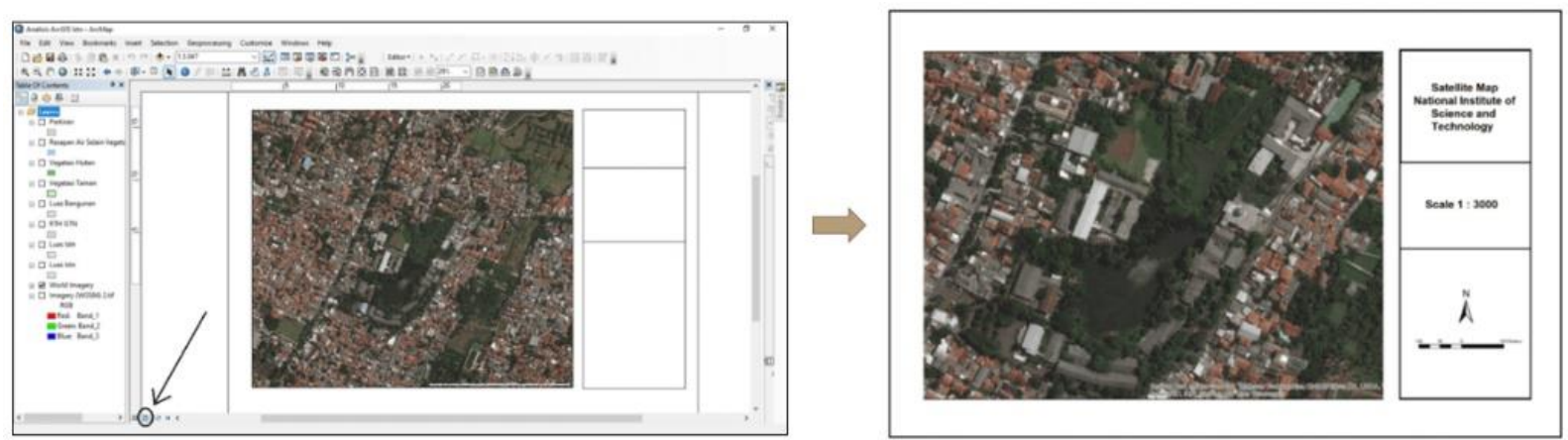

Figure 1 Obtaining and scaling the satellite map using ArcGIS

\subsection{Data Collection}

The data required for the analysis is obtained from the results of the site surveys and the analysis of the ISTN campus area using the ArcGIS application. The area is calculated in the application by creating a polygon delineating the boundaries of the campus. Figures 2 and 3 show examples of the selected polygon and the calculation result.

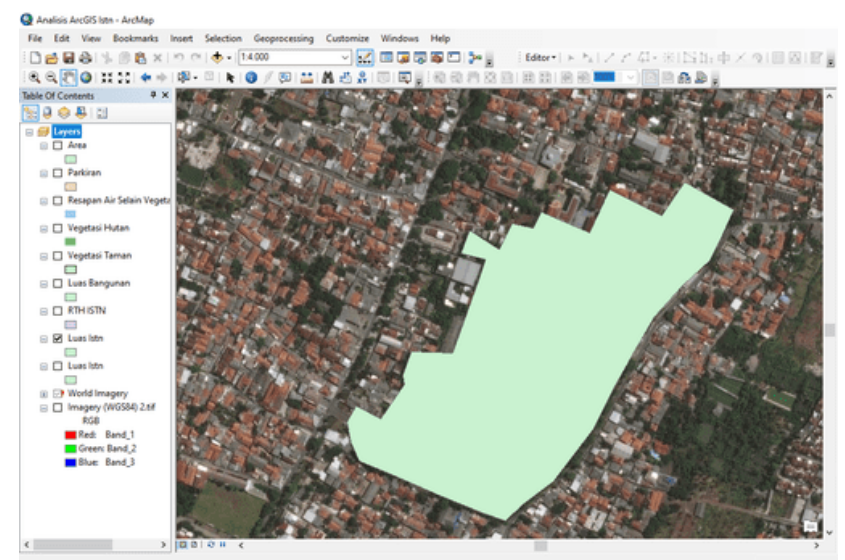

Figure 2 The polygon of the ISTN campus area

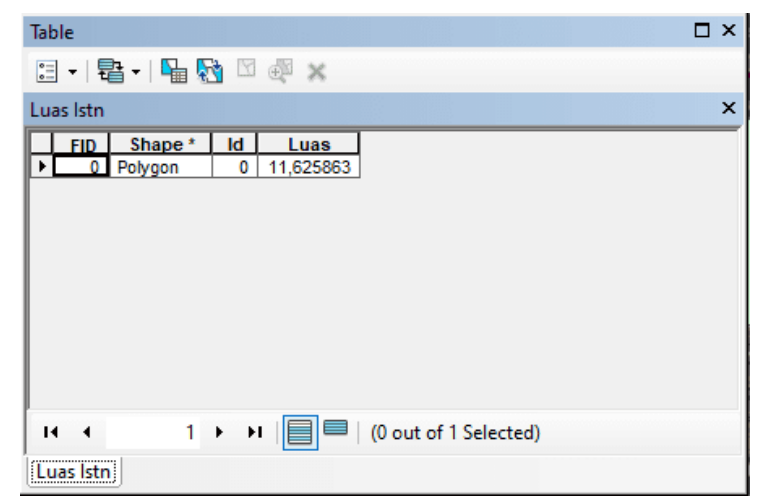

Figure 3 The total area of the ISTN campus

The ratio of the forest vegetation area, plant or garden vegetation area, parking area, and the area of green open space to the total area is calculated using the following formula:

$$
\text { Ratio of searched area to campus area }=\frac{\text { Searched } \text { Area }}{\text { Campus Area }} \times 100 \%
$$

This formula is used to obtain the ratios that are considered in several categories of the UI GreenMetric guidelines and are part of the analysis method. 


\subsection{Design and Analysis Method}

\subsubsection{Analyzing total score UI GreenMetric for ISTN campus area}

To analyze the total UI GreenMetric score, the calculated area were analyzed according to the categories of the UI GreenMetric guidelines. The total UI GreenMetric score of the existing ISTN campus is obtained to find out what categories can be improved and added.

As mentioned before, there are six categories in the UI GreenMetric guidelines: Settings and Infrastructure (SI), Energy and Climate Change (EC), Waste (WS), Water (WR), Transportation (TR), and Education and Research (ED). Table 1 shows the percentage each category has in the overall analysis.

Table 1 Percentage of UI GreenMetric parameters (UI GreenMetric, 2021)

\begin{tabular}{clc}
\hline No. & \multicolumn{1}{c}{ Category } & $\begin{array}{c}\text { Percentage from Total } \\
\text { Point (\%) }\end{array}$ \\
\hline 1. & Setting and Infrastructure (SI) & 15 \\
2. & Energy and Climate Change (EC) & 21 \\
3. & Waste (WS) & 18 \\
4. & Water (WR) & 10 \\
5. & Transportation (TR) & 18 \\
6. & Education and Research (ED) & 18 \\
\hline \multicolumn{2}{c}{ Total } \\
\hline
\end{tabular}

\subsubsection{Design method}

The goal of the design process is to create a master plan design for the campus, improving or adding the facilities to increase the ISTN campus total score based on the UI GreenMetric guidelines. A 3D map design, or master plan, will be used as a basic plan for modelling a green campus design. The 3D map design method in this paper uses the Cadmapper and Sketchup applications.

A 3D map is obtained from the cadmapper.com website: the online application processes the selected the area and outputs a 3D map of the location as a .skp file, which can then be used in the Sketchup application, where the parameters taken from the UI GreenMetric guidelines can be implemented.

\subsubsection{Analysis of green campus master plan design}

After the green campus master plan design is complete, the total UI GreenMetric score is analyzed again and compared with the results of the campus before and after the redesign to determine the percentage of the score increase.

\section{Results and Discussion}

\subsection{ISTN Campus Area Total UI GreenMetric Score}

The total score for each category of the UI GreenMetric ranking is obtained for the existing campus by calculating the ratio of the green open space to the total area in the relevant setting and infrastructure category. Below is an example of the calculation refers to Equation 1:

The ratio of green open space area to campus area $=\frac{\text { Green Open Space Area }}{\text { Campus Area }} \times 100 \%$

The ratio of green open space area to campus area $=\frac{8}{11.62} \times 100 \%=68.8 \%$

Based on the ArcGIS calculation, the campus area is 11.62 hectares and the green open space is 8 hectares. Therefore, the ratio of the green open space area to the campus area is $68.8 \%$. 
Table 2 Example of score calculation area

\begin{tabular}{clcc}
\hline No. & \multicolumn{1}{c}{ Criteria } & Maximum Score & Score \\
\hline \multirow{2}{*}{ SI 1} & Setting and Infrastructure (SI) & & \\
& The ratio of the open space area to the total area & 200 & 0 \\
& $\leq 1 \%$ & & $0.25 \times 200$ \\
& $>1-80 \%$ & & $0.50 \times 200$ \\
& $>80-90 \%$ & $0.75 \times 200$ \\
& $>90-95 \%$ & & $1.00 \times 200$ \\
\hline & $>95 \%$ & & 50 \\
\hline
\end{tabular}

The ratio of the green open space area to the campus area gets the score of 50 points based on the UI GreenMetric guidelines (Table 2). The overall results for other categories are shown in Table 3.

Table 3 UI GreenMetric score for existing ISTN campus

\begin{tabular}{clc}
\hline No. & \multicolumn{1}{c}{ Category } & Point \\
\hline 1. & Setting and Infrastructure (SI) & 450 \\
2. & Energy and Climate Change (EC) & 300 \\
3. & Waste (WS) & 600 \\
4. & Water (WR) & 600 \\
5. & Transportation (TR) & 700 \\
6. & Education and Research (ED) & 200 \\
\hline \multicolumn{2}{c}{ Total }
\end{tabular}

The total UI GreenMetric score for the existing ISTN campus is 2,850 points, or $28.5 \%$.

\subsection{D Map (Green Campus Master Plan Design)}

The 3D map is designed to plan the placement of several infrastructures within the campus area to meet the standards of the UI GreenMetric categories.

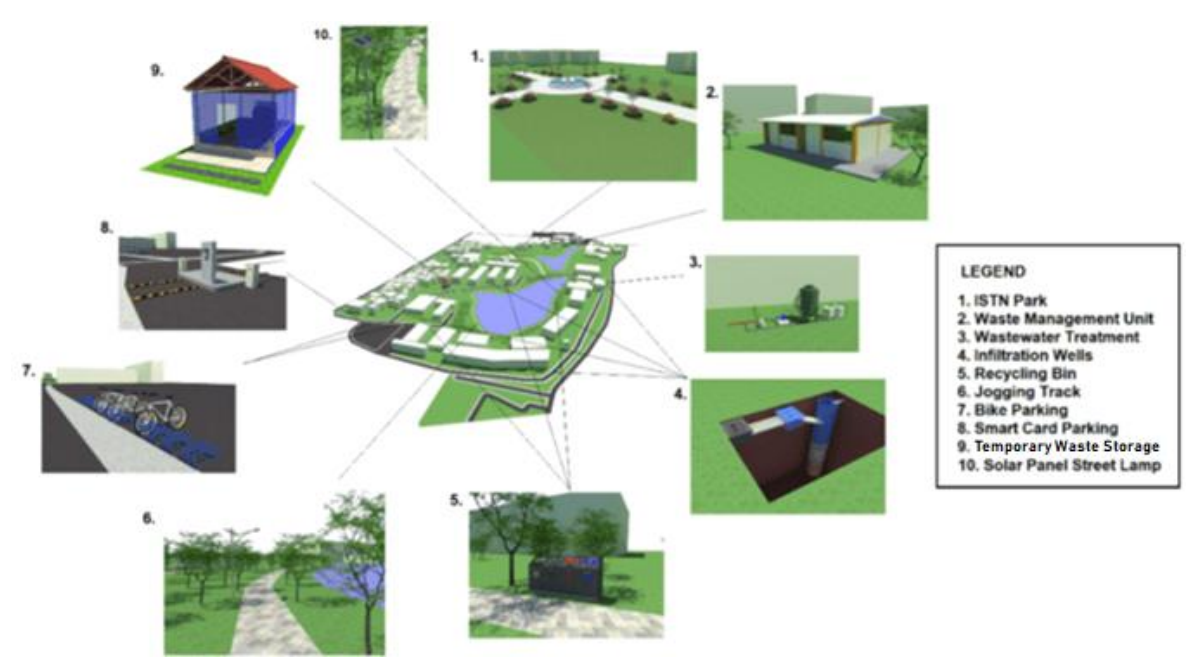

Figure 4 ISTN Green campus master plan design

Details of the design:

1. ISTN park

The designed ISTN park is 60 meters long and 20 meters wide (the total area is 1,200 $\mathrm{m}^{2}$ ). Adding a garden and therefore increasing the plant/garden vegetation (50 points under the Settings and Infrastructure category). 
2. Waste management unit

The waste management unit is designed as a waste processing center to reduce the waste burden in the campus area and add a recycling program to the campus (300 points under the Waste category). The program includes such aspects as a recycling bin design and waste treatment, with the waste management units processing more than $75 \%$ organic waste (300 points); a waste management unit design also provides an efficient sewage disposal system (300 points).

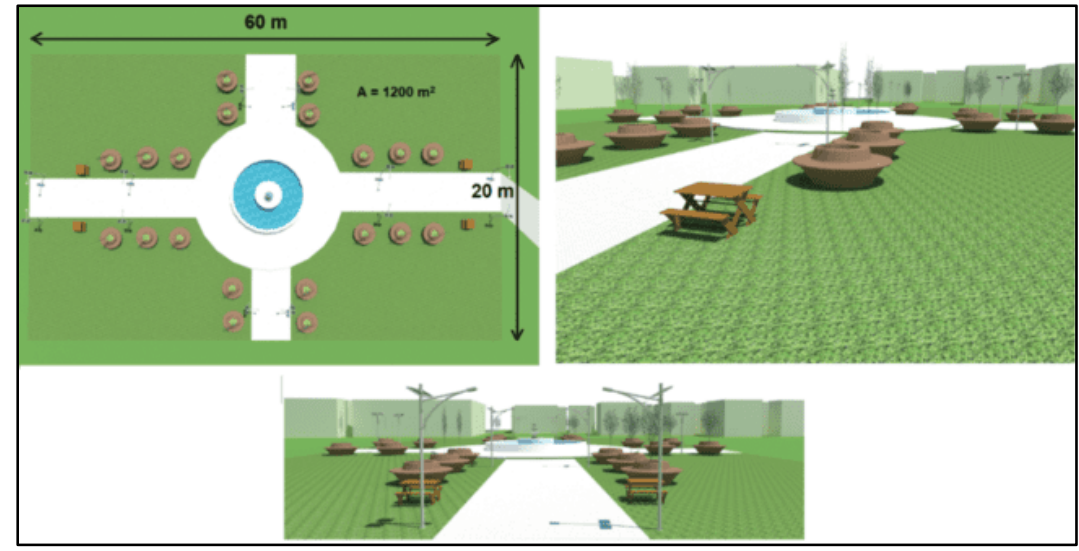

Figure 5 ISTN park

3. Wastewater treatment

The wastewater treatment unit processes water waste into water suitable for consumption, or clean water. This design adds a water recycling program to the ISTN campus and helps recycle more than $50 \%$ of water used by installing infiltration wells, ensuring water recycling (200 points under the Water category) and efficient use of water for such facilities as toilet and handwashing (200 points for waterefficient appliances usage). In addition, the campus area can implement treatment of $1-25 \%$ of the consumed water, which yields 50 more points under the treated water consumed criterion.

4. Infiltration wells

Infiltration wells store rainwater that can be used when needed. The proposed design allows the ISTN campus to recycle more than $50 \%$ of recycled water.

5. Recycling bin

The recycling bin is a place of garbage disposal with an organic and inorganic waste sorting system, which is important for waste management and treatment and ensures the campus stays clean. Implementation of a recycling program yields 300 points under the Waste category.

6. Jogging track

The two-meter-wide jogging track is located inside the ISTN lakes area, three meters away from the lake bank. This design adds safe pedestrian paths to the campus (150 points under the Transportation category).

7. Bike parking

Designed to reduce the number of vehicles (cars and motorcycles) in the campus area and reduce pollution in the campus area by encouraging the students to use bicycles, the bike parking design is meant to reduce pollution in the campus area (100 points under the Transportation category). 
8. Smart card parking

Smart card parking is designed to reduce the number of vehicles (cars and motorcycles) in the campus area, encouraging students or residents to come to the campus by other means of transport, such as bicycles.

9. Temporary waste storage

Temporary waste storage stores organic and inorganic waste before it is processed in the waste management unit. This facility is part of the waste management system of the campus (300 points under the Waste category) featuring a recycle bin design and waste management unit ensuring an efficient waste and sewage disposal system.

10. Solar panel streetlamp

Solar panel street lamps derive electrical energy from sunlight, reducing carbon emissions at the ISTN campus. This design adds a source of renewable energy to the campus (75 points under the Energy and Climate Change category).

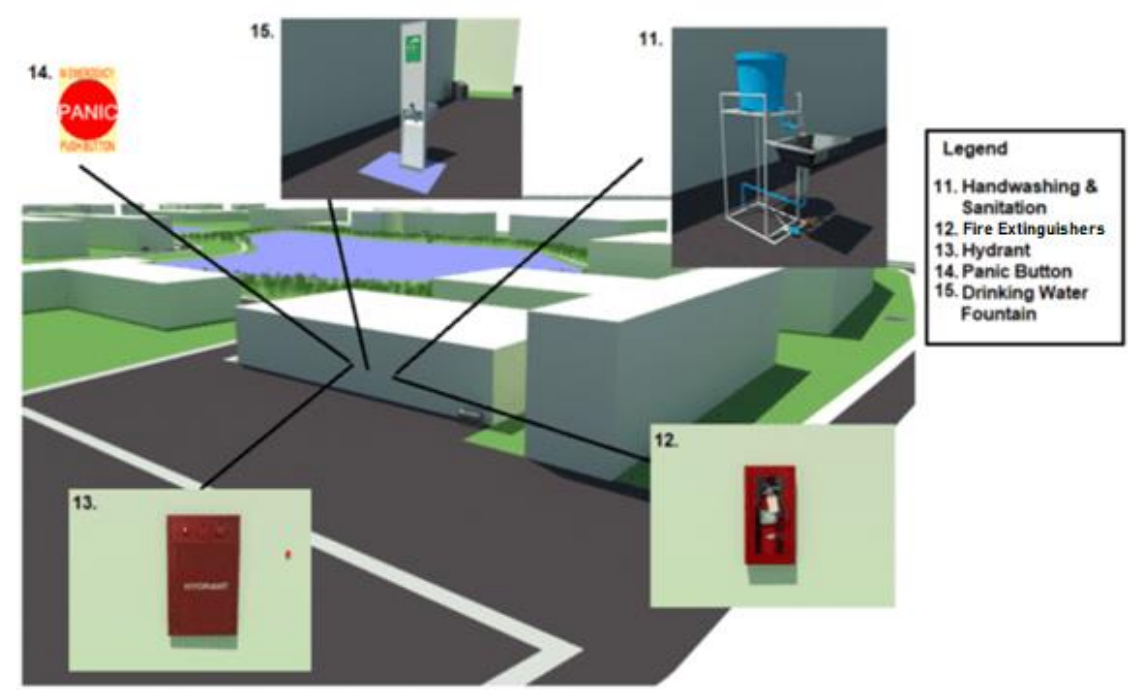

Figure 6 Building support facilities' design

11. Handwashing and sanitation

The handwashing and sanitation cleaning facilities are especially important for the COVID-19 pandemic because this facility can help maintain hand hygiene and reduce virus transmission (200 points under the Water category). This design allows for handwashing and sanitation facilities to be installed in $75-80 \%$ of the campus buildings.

12. Fire extinguishers

Fire extinguishers are installed to help extinguish small fires and prevent large fires, minimizing injuries and damage of the property. ISTN employs trained personnel and has CCTV cameras installed, ensuring security and safety on campus (100 points under the Setting and Infrastructure category).

13. Hydrant

The hydrant is installed to extinguish large fires and give firefighters access to water, contributing thereby to the safety and security at the campus

14. Panic Button

The panic button is an emergency button installed to call a security officer in case of an accident on campus, allowing security officers to respond faster (contributes to 
the 75 points for security and safety facilities under the Setting and Infrastructure category).

15. Drinking-water fountain

The drinking water fountain is a water supply facility suitable for consumption. This facility is designed to reduce the use of paper and plastic and the drinking water fountain is designed at all building ( 75 points under Waste category).

\subsection{Analysis of Green Campus Master Plan Design Total Score}

After the green campus master plan design is completed and the total UI GreenMetric score is recalculated in accordance with the 2021 UI GreenMetric guidelines, the results of the total score for the proposed ISTN campus design are shown in Table 4.

Table 4 Total score for ISTN green campus design

\begin{tabular}{clr}
\hline No. & \multicolumn{1}{c}{ Category } & Point \\
\hline 1. & Setting and Infrastructure (SI) & 500 \\
2. & Energy and Climate Change (EC) & 375 \\
3. & Waste (WS) & 1275 \\
4. & Water (WR) & 850 \\
5. & Transportation (TR) & 950 \\
6. & Education and Research (ED) & 200 \\
\hline
\end{tabular}

The total UI GreenMetric score for the ISTN green campus master plan design is 4,150, or $41.50 \%$, compared to the initial result of 2,850 , or $28.5 \%$. Therefore, the ISTN green campus master plan design contributes to creating a more environmentally friendly and sustainable campus increasing the score by 1,300 points, the education and research is not designed because that refers to campus policy and that are not physical, while the green campus master plan designed refers to physical design.

\section{Conclusions}

The green campus master plan design proposes to implement 15 infrastructures at the ISTN area: a park, jogging track, waste management unit, wastewater treatment facility, infiltration wells, a recycling bin, bike parking, smart card parking, temporary waste storage, solar panel streetlamps, handwashing and sanitation facilities, fire extinguishers, a hydrant, a panic button, and a drinking water fountain at all building. The new design yields 4,150 total UI GreenMetric score (an increase by 1,300 points) to the campus area and makes the ISTN campus more environmentally friendly and sustainable compared to the existing design, which yields 2,850 points.

\section{Acknowledgements}

The authors of the research thank Universitas Indonesia and UiTM for supporting their work with the grant program Bilateral Strategic Alliance (Ui-Uitm Bisa) Research Collaboration Agreement (Matching Grant) Year 2021-2022, number NKB679/UN2.RST/HKP.05.00/2021.

\section{References}

Abdallah, A.E., 2018. Toward Sustainable Campuses in Egypt Case Study Mansoura University. International Journal of Scientific and Engineering Research, Volume 9(6), pp. 1050-1058 
Atici, K.B., Yasayacak, G., Yildiz, Y., Ulucan, A., 2020. Green University and Academic Performance: An Empirical Study on UI GreenMetric and World University Rankings. Journal of Cleaner Production, Volume 291, pp. 01-11

Berawi, M.A., 2021. Managing Cross-Sectoral Coordination in Accelerating the Sustainable Development Agenda. International Journal of Technology, Volume 12(2), pp. 228-231

Binta, I., Maulana, D., 2021. Evaluasi Penataan dan Infrastruktur Kampus Hijau pada Politeknik Negeri Pontianak Berdasarkan UI GreenMetric (Evaluation of Green Campus Arrangement and Infrastructure at Pontianak State Polytechnic Based on UI GreenMetric). Gewang: Gerbang Wacana, dan Rancang Arsitektur, Volume 3(1), pp. 2530

Dagiliūtè, R., Liobikienè, G., Minelgaitè, A., 2018. Sustainable at Universities: Students' Perceptions from Green and Non-Green Universities. Journal of Cleaner Production, Volume 181, pp. 473-482

Le, U.V., 2018. The Sustainability Efforts of Ton Duc Thang University in the South of Vietnam. E3S Web of Conferences, Volume 48, pp. 01-02

Parvez, N., Agrawal, A., 2019. Assessment of Sustainability Development in Technical Higher Education Institutes of India. Journal of Cleaner Production, Volume 214, pp. 975-994

Russ, N.M., Hamid, M., Ye, K.M., 2018. Literature Review on Green Cost Premium Elements of Sustainable Building Construction. International Journal of Technology, Volume 9(8), pp. $1715-1725$

Santoso, N.D., Akmalah, E., Irawati, I., 2017. Implementasi Konsep Green Campus di Kampus Itenas Bandung Berdasarkan Kategori Tata Letak dan Infrastruktur (Implementation of the Green Campus Concept at Itenas Bandung Campus Based on Layout and Infrastructure Categories). RekaRencana: Jurnal Teknik Sipil, Volume 4(3), pp. 139-150

Suwartha, N., Berawi, M.A., 2019. The Role of UI GreenMetric as a Global Sustainable Ranking for Higher Education Institutions. International Journal of Technology, Volume $10(5)$, pp. 862-865

UI GreenMetric, 2021. Universities, UI GreenMetric, and SDGs in the Time of Pandemic. Guideline UI GreenMetric World University Rankings 2021, pp. 7-9 